\title{
Are reported greenhouse gas emissions influencing corporate financial performance?
}

\author{
Elena-Mirela Nichita ${ }^{\mathrm{a}, 1}$, Elena Nechita ${ }^{\mathrm{a}}$, Cristina-Lidia Manea ${ }^{\mathrm{a}}$, \\ Alina Mihaela Irimescu ${ }^{\mathrm{a}}$ and Diana Manea ${ }^{\mathrm{a}}$ \\ ${ }^{a}$ Bucharest University of Economic Studies
}

\begin{abstract}
Research Question: This paper aims to analyse the impact of reported greenhouse gas (GHG) emissions on financial performance of companies operating in the chemical industry from Central-Eastern Europe over the period 2015-2019.

Motivation: Currently, the climate change and global warming have become highly topical due to their progressively visible destructive effects worldwide on the environment, society, and economic activity.

Idea: To offer the suitable information to all its stakeholders, each company should identify the necessary information, measure it, make it useful, and take reasonable steps to ensure that it's accurate; our research investigates the effect of reported greenhouse gas emissions on return on sales, as a measure of business performance.
\end{abstract}

Data: The paper is based on panel data extracted from non-financial and/or annual reports for the top 10 largest companies operating in the chemical industry geographically located in Central-Eastern Europe covering the time frame 2015-2019. The final sample consists of 34 firms and 134 firm-year observations.

Tools: A multiple linear regression model was designed and applied, having return on sales as the dependent variable and GHG emissions as the independent variable.

Findings: The findings of our study confirm that a lower level of GHG emissions will generate an increase in return on sales, consequently, the environmental performance reported in terms of controlling for GHG emissions enhances the financial performance measured as return on sales ratio.

Contribution: The paper contributes to the literature on climate change, revealing a negative, but significant effect of GHG emissions on financial performance and endorsing that companies which today pay less attention to this global concern, tomorrow will face difficulties in terms of sales.

1 Corresponding author: Elena-Mirela Nichita, Department of Accounting and Audit, Bucharest University of Economic Studies, Piața Romană, no. 6; tel. (+40) 745.972.468; email address: mirela.nichita@cig.ase.ro 
Keywords: GHG emissions, return on sales, climate change, environmental performance, financial performance, Central-Eastern European countries (CEE countries), stakeholders

JEL codes: M41, Q01, Q54

\section{Introduction}

As sustainability is a concern of the global marketplace, questions emerge about how environmental and social sustainability might amend the role of reporting, both from financial and non-financial perspectives.

Climate change disclosure represents part of the infrastructure for providing decision-makers with information that will enable them to integrate climate considerations into their analysis to help better align business practices with climate change mitigation, resilience plans and sustainable development goals. Thus, corporations find themselves under growing pressure from multiple stakeholders to increase the quality, quantity, and availability of climate change related information (OECD, 2015).

All sectors of the economy face major disruptions from climate transition and climate impacts, yet the majority of companies in key industries are still not engaging significantly in dealing with these risks or positioning themselves to take advantage of potential opportunities, as assessing climate-related risks and opportunities can be complex and may require detailed analysis (EY, 2019).

The researchers' interest in climate change was manifested by studying urban climate governance (Heijden, 2019), identifying new and more effective solutions to climate challenges (Trutnevyte et al., 2019), or examining the effects of environmental performance on financial performance (Dowell et al., 2000; Fujii et al., 2013; Wang et al., 2015).

This study focuses on one particular element of corporate social responsibility (CSR) which is becoming increasingly important - climate change - and contributes to the literature on this issue by investigating the effects of reported GHG emissions on corporate financial performance (CFP) of companies operating in the chemical industry in Central and Eastern European (CEE) countries. The main conclusion of our study is that the reported GHG emissions have a negative influence on financial performance.

To accomplish our objective, the paper is organised as follows: the literature review section describes the role of stakeholders' theory in reporting GHG emissions and the relationship between GHG and financial performance under voluntary 
disclosure policies; the methodology details the approaches and procedures used in selecting the data, the results and discussion section provides our insights in respect to SDG 13 disclosures and performance measured as return on sales (ROS). The paper ends with a discussion section, limitations of investigation, conclusions, and future research agenda on this subject.

\section{Literature review}

Starting with Carson's writing (1962), a transformation in the relationship between humans and the natural world encouraged an awakening of the public regarding environmental consciousness.

Businesses in all sectors and of every size face essential questions about adapting to climate change and its associated risks and regulations. The embrace of efforts for mitigating climate change as a strategic imperative will become critical to their overall long-term sustainability (CIMA, 2010). There is growing recognition among corporates that climate change may cause a substantial transformation of businesses as well as bringing new opportunities. Nevertheless, an extensive knowledge gap exists in terms of the requirements to create a net zero-carbon business (KPMG, 2015).

In the academic literature, the theories used in explaining the drives of voluntary GHG reporting are socio-political theories, economic theories and institutional theories. This paper is selecting the stakeholder theory (Freeman, 1984; Roberts, 1992) as theoretical background for exploring the GHG reporting and numerous academic studies are considering it appropriate when discussing natural environment (Cormier et al., 2005; Ghomi \& Leung 2013; Jaggi et al., 2018b; Sprengel \& Busch, 2010; Retolaza et al., 2016). The advocates of this theory argue that managers may use GHG disclosures as a channel of communication with various groups of individuals (Gray et al., 1995). Businesses have been dealing with an increasing pressure to assess, reduce and report their GHG emissions from different types of stakeholders, such as investors, consumers, suppliers, governments, financial institutions, media, non-governmental organisations and the general public, as corporate activities have a significant effect on the global GHG emissions, directly or indirectly. Corporations have a strong incentive to respond to stakeholders' demands for information on their pollution-related activities, which will demonstrate that they are complying with their expectations. Large entities have more resources to invest in climate disclosures (Belal, 2001) and are determined to build a positive image towards their stakeholders. Companies in the mining, oil and chemical sectors seem to disclose more information regarding environmental management and employees' health and safety measures (Line et al., 2002). The investigation conducted by Halkos and Skouloudis (2016) on a sample of Greek companies endorses that the climate change discourse is an instrument of empowering 
stakeholders' decision-making. The incentives that businesses face to reveal or conceal emissions in voluntary reporting schemes, under- or over-reporting, depend largely on expectations of future legislative policies, therefore the governments should be more active in demanding climate related disclosures.

Investors, customers, employees, general public are often in a position to exert informal pressure on organisations to improve their social and environmental sustainability performance.

In a longitudinal analysis, covering the period 1990-2017, Iordache et al. (2021) reveal that the GHG emissions level in 2017 had declined by approximately $25 \%$ in comparison with the reference year (1990). A decrease of GHG emissions in the European Union by an average of $1 \%$ annually can be explained by a mixture of factors: resizing of the industry, improving energy efficiency, the growing share of renewables and less use of carbon fuels. At the country level, the data published by the European Environment Agency (EEA, 2019) indicates the decrease in GHG emissions for Romania by $54 \%$, Czech Republic by $34 \%$, Hungary by $31 \%$, Poland by $12 \%$, and Slovakia by $40 \%$ for the period $1990-2017$.

A systematic examination on how climate change reporting impacts the financial performance of corporations leads to inconsistent results: positive (value creation), negative (value destruction), and inconclusive. This was expected since more than 100 studies that have empirically examined the more general relationship between corporate social responsibility and corporate financial reporting have resulted in inconsistent findings for this linkage (Wang et al., 2015). The value creation approach regards environmental efforts as a way to increase competitive advantage and improve financial returns to investors. The relationship between environmental performance, including climate change reporting, and market value (Tobin's q) or return on assets ratio (ROA) or return on sales (ROS) is expected to be positive according to this view (Albertini, 2013; Dowell et al., 2000; Clarkson et al., 2011; Cotter \& Najah, 2011; Iwata \& Okada, 2011; Fujii et al., 2013; Gnanaweera \& Kunori, 2016; Konar \& Cohen 2000; Lopez-Gamero et al., 2009; Manrique \& MartiBallester, 2017). The value destruction view argues that environmental investments and high environmental performance represent only increased costs, triggering decreased earnings and lower market values. Consequently, the relationship between environmental performance and financial indicators, expressed as ROA or market value is confirmed to be negative in several studies (Garcia-Sanchez \& PradoLorenzo, 2012; Sarkis \& Cordeiro, 2001; Trumpp \& Guenther, 2017; Walley \& Whitehead, 1994; Wang et al., 2014). Research papers published by McWilliams and Siegel (2000), Moore (2001), and Budiharjo (2019) did not endorse neither a positive nor a negative relationship between environmental reporting and financial performance. 
There is still great reticence among investors with respect to behaviours that attend to the natural environment, but also acknowledged growing interest. Investors, as central financial stakeholders, are looking both for corporations to report their environmental impacts and for new instruments, such as weather derivatives to hedge their risk or provisions (Hoffman \& Bansal, 2011).

Although it is difficult to estimate how much companies should be disclosing, it is clear that many companies are failing to make public climate change risks; Doran and Quinn's (2009) paper concluded that in 2013 more than $40 \%$ of S\&P 500 member companies failed to make any mention of climate change in their annual reports. On the other hand, some researchers acknowledged that large firms disclose the most environmental information (Albertini, 2014; Chauvey et al., 2015), presumably due to greater visibility, greater social and political and stakeholders' pressures, and may use these disclosures as a tool to reduce those exposures (Patten, 2002).

Gamble et al. (1995), Gray et al. (2001) and Shih et al. (2006) pointed out that sectors with long-term cumulative pollution problems, including high-pollution sectors such as the oil sector, chemical sector, and steel sector, are more likely to take the initiative to disclose environmental information.

Scholars have empirically investigated the relationship between environmental and financial performance for several decades with varying results from positive to negative, from significant to insignificant, or even inconclusive. They all tried to find explanations to argue for their results referring to the horizon of time the financial performance was measured for (short-term or long-term performance) or bringing into discussion the economies from which the companies were selected (advanced or developing economies), but also the industry type (clean or dirty industries). Enrolling in the CSR-CFP relationship research, our study analyses the impact of climate change on the financial performance of companies. For assessing the impact on climate, the greenhouse gases data was collected and analysed, as the GHGs from human activities are the most significant driver of observed climate change since the mid-20 $0^{\text {th }}$ century (IPCC, 2013). As measures of financial performance, the above academic literature indicates return rates such as return on assets (ROA), return on sales (ROS), and return on equity (ROE) as indicators of short-term financial performance and Tobin's q as an indicator of the potential long-term value of the performance. For the research hypothesis, we used the return on sales (ROS) as a measure of financial performance to examine the relationship between GHG emissions and financial performance, as argued in the dependent variable section. $\mathrm{H}$ : A lower level of GHG emissions will generate an increase in return on sales.

To test this hypothesis, a methodology based on multiple linear regression model is applied and disclosed in the further section. 


\section{Research methodology}

Emissions of several important greenhouse gases that result from anthropic activity have increased substantially since large-scale industrialization began, and the industry still remains one of the main contributors to air pollution. Over time, climate change becomes perhaps the most serious of environmental concerns (Pinkse \& Kolk, 2009), dealing with the release of pollutants in the air. Although all organizations in the global economy are contributing to the negative effects on climate, there are industries that are more polluting than others. According to the European Environment Agency (EEA, 2021), the chemical industry is one of the top 10 main polluting industries, in terms of air and water pollution, as well as waste generation. Considering this significant impact on climate change, our analysis is focused on the chemical sector companies, thus removing the disadvantage of measuring the environmental performance based on pollution emissions of firms in relatively low polluting industries, as argued by Stanwick and Stanwick (1998). The criterion used for selecting the first 5 Central and Eastern European (CEE) countries included in the analysis was based on the gross value added (GVA), resulting in the selection of the following countries: Poland (PL), Czech Republic (CZ), Romania (RO), Hungary (HU) and Slovakia (SK).

\subsection{Sample description}

The sample of companies used in our research study was drawn from the ISI Emerging Markets Group's EMIS platform database (ISI, 2020), based on firms' operating revenue. The first 20 chemical companies were selected for each of the 5 CEE countries included in the analysis for the period 2015-2019. This time frame is appropriate for our analysis because it tracks the efforts the companies have made immediately after the introduction of the 17 UN Sustainable Development Goals. The initial sample included 100 companies and it was refined based on the availability of individual or group companies' reports in English on their websites (considering all types of reports, from sustainability and CSR reports to annual financial reports), in order to avoid any biases associated with translation and to collect all necessary financial information for the multiple linear regression analysis. Thus, the sample was reduced to 38 companies with 161 firm-year observations. Furthermore, due to the lack of information regarding the GHG emissions measurements, the sample was once again diminished to 34 companies, corresponding to 135 firm-year observations. As part of the regression analysis, one outlier that resulted has been truncated, leading to a final sample that consists of 34 companies with a number of 134 firm-year observations. 


\subsection{Research design}

\section{Dependent variable}

According to previous studies (De Burgos-Jiménez et al., 2013; Earnhart \& Lizal, 2007; Elsayed \& Paton, 2004), the dependent variable used is return on sales (ROS), a short-term measure of financial performance. Return on sales is computed as a ratio between net income and the value of sales (Elsayed \& Paton, 2004), representing a good measure of financial performance since it indicates how effectively companies are able to convert sales into profits (Rassier, 2005). Additionally, using this ratio, we mitigate any concerns on the measurement of inflation (Earnhart \& Lizal, 2007).

\section{Independent variable}

The independent variable is represented by GHG emissions, as a measure of climate change similar to prior studies (Earnhart \& Lizal, 2007; Elsayed \& Paton, 2004; Fujii et al., 2013; García-Sánchez \& Prado-Lorenzo, 2012; Wang et al., 2014). These emissions consist of seven gases with a direct effect on climate change. Among these various greenhouse gases produced by human activities, $\mathrm{CO}_{2}$ is the largest contributor to climate change.

The values for GHG emissions reported by companies are gathered and converted into $1,000 \mathrm{t} \mathrm{CO}_{2}$ equivalent $\left(\mathrm{CO}_{2} \mathrm{e}\right)$, which is a metric measure that is used to compare emissions from various greenhouse gases on the basis of their global warming potential. The greenhouse gas emissions measured for Scope 1 - Direct emissions generated within own facilities, Scope 2 - Indirect emissions from purchased energy, and Scope 3 - Indirect emissions in the value chain were considered in the analysis. Consistent with Delmas et al. 2015, natural logarithm conversions are applied to adjust for the skewed distribution of GHG emissions.

\section{Control variables}

To enhance the internal validity of the model, control variables that may influence firms' financial performance are used, such as firm's size, growth, change in liabilities, and cash flows. All these variables are detailed in Table 1.

Table 1. Control variables definition and measurement

\begin{tabular}{|c|c|}
\hline Variable & Measurement and relevant studies \\
\hline SIZE & $\begin{array}{l}\text { Natural logarithm of total assets (Goll \& Rasheed, 2004; Grimaldi et al., 2020; } \\
\text { Hussain et al., 2018; Kuzey \& Uyar, 2017; Mishra \& Suar, 2010; Webe, 2017) }\end{array}$ \\
\hline GROWTH & Annual change in sales divided by total sales (King \& Lenox, 2002) \\
\hline DISSUE & Annual change in total liabilities (Barth et al., 2008) \\
\hline $\mathrm{CF}$ & Total cash divided by total assets (Barth et al., 2008) \\
\hline COUNTRY & $\begin{array}{l}\text { Binary dummy variable for each country (RO omitted, set as reference); the variable } \\
\text { equals } 1 \text { if country is } k \text { (where } k=1-4 \text {, for each of the countries CZ, HU, PL and } \\
\text { SK), and } 0 \text { otherwise }\end{array}$ \\
\hline YEAR & $\begin{array}{l}\text { Binary dummy variable for each year ( } 2015 \text { omitted, set as reference); the variable } \\
\text { equals } 1 \text { if the year is } \mathrm{k} \text { (where } \mathrm{k}=1-4 \text {, for each of the years } 2016,2017,2018 \text { and } \\
\text { 2019), and } 0 \text { otherwise }\end{array}$ \\
\hline
\end{tabular}


Furthermore, to reduce concerns on any association between the dependent and independent variables, dummy variables for countries (COUNTRY) and years (YEAR) are used in the regression model (Bartlett, 2012; et al., 2019; Mummolo \& Peterson, 2018).

\subsection{Data analysis}

The applied multiple linear regression model is based on the previously defined variables, as shown below:

$$
\begin{gathered}
\text { ROS }=\alpha_{0}+\alpha_{1} \text { GHG emissions }_{i t}+\alpha_{2} \text { SIZE }_{\text {it }}+\alpha_{3} \text { GROWTH }_{\text {it }}+\alpha_{4} \text { DISSUE }_{i t}+ \\
\alpha_{5} \text { CF }_{\text {it }}+\alpha_{6} \text { COUNTRY }_{\text {kit }}+\alpha_{7} \text { YEAR }_{k i t}+\varepsilon_{i t}
\end{gathered}
$$

To ensure the statistical validity of the regression model, several procedures were applied. The linear relationships between variables were checked by plotting a scatterplot of the studentized residuals against the (unstandardized) predicted values and partial regression plots between each independent variable and the dependent variable. The absence of multicollinearity was verified by examining both the Pearson correlation coefficients and tolerance / variance inflation factor (VIF) values (Hair et al., 2014). The resulted outlier based on casewise diagnostics was truncated, with no impact on the number of companies, but only on firm-year observations. There were no studentized deleted residuals greater than \pm 3 standard deviations, no leverage values greater than 0.2 (Huber, 1981), and no values for Cook's distance above 1 (Cook, 1982).

Having all statistical criteria met, running the multiple linear regression was appropriate and the results are detailed in the further section. IBM SPSS Statistics 27 was used as software resource.

\subsection{Empirical results}

\section{Descriptive statistics}

The descriptive statistics (mean, median, standard deviation, minimum, and maximum) values for the independent, dependent, and control variables that were included in the regression model, for all 135 observations (before truncating the outlier) are detailed in Table 2. 
Are reported greenhouse gas emissions influencing corporate financial performance?

Table 2. Descriptive statistics

\begin{tabular}{cccccc}
\hline Variable & Mean & Median & Std. Deviation & Minimum & Maximum \\
\hline ROS & 0.0927 & 0.0812 & 0.1275 & -0.7348 & 0.5692 \\
GHG emissions & 7.3869 & 7.6309 & 2.6794 & 0.0200 & 11.9300 \\
SIZE & 23.1533 & 23.8289 & 2.1440 & 17.7855 & 25.6678 \\
GROWTH & 0.0512 & 0.0363 & 0.1849 & -0.2559 & 1.5020 \\
DISSUE & 0.0920 & 0.0343 & 0.2584 & -0.3200 & 1.4673 \\
CF & 0.0208 & 0.0127 & 0.0633 & -0.1982 & 0.3935 \\
\hline
\end{tabular}

Note: $\mathrm{N}=135$ observations

Although the dependent variable (ROS) is taking values from a positive maximum of 0.5692 to a negative minimum of -0.7348 , the majority of the companies have positive return on sales rates as the median emphasises. In the case of GHG emissions, there is a significant difference between the maximum value of 11.9300

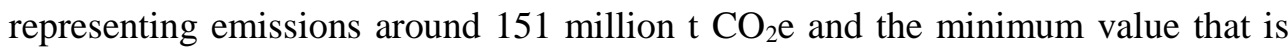
close to zero. Furthermore, we note that the mean of GHG emissions is also remarkably high, showing a great level of air pollution with negative impact on climate. Regarding the SIZE used as a control variable, the mean of 23.1533 is very close to the median, indicating that the values are symmetrically distributed.

Subsequent, the association between variables along with the multicollinearity assumption were tested by applying the Pearson correlation analysis. As presented in Table 3, our findings indicate some statistically significant correlations at the 0.01 level. A single coefficient indicates a strong correlation of 0.648 significant at the $1 \%$ level between our independent variable (GHG emissions) and the firm's size (SIZE), which confirms that larger firms generate more GHG emissions. However, the coefficient is still below the upper limit of Pearson's accepted level of 0.7, that might signal multicollinearity issues. The other values presented in the Pearson matrix show low positive or negative correlations. Low positive associations are mostly found between the dependent variable (ROS) and all other variables, and low negative correlations may be observed among the control variables.

Table 3. Pearson correlation matrix

\begin{tabular}{cccccc}
\hline Variables & ROS & GHG emissions & SIZE & GROWTH & DISSUE \\
\hline ROS & - & & & & \\
GHG emissions & 0.006 & - & & & \\
SIZE & $0.289^{*}$ & $0.648^{*}$ & - & & \\
GROWTH & 0.101 & -0.012 & -0.059 & - & - \\
DISSUE & $0.257^{*}$ & -0.081 & -0.016 & -0.007 & -0.036 \\
CF & $0.255^{*}$ & 0.002 & -0.004 & 0.009 & \\
\hline
\end{tabular}

Note: $*$ Correlation is significant at the 0.01 level (2-tailed). 
As the correlation coefficients are indicating low associations and all tolerance and VIF values are within the accepted thresholds (with detailed information provided in the regression results section), the regression was compiled without facing any multicollinearity biases.

(a) Regression results - entire sample

Our results show that the regression model is statistically significant at the level of $1 \%$. The independent variable (GHG emissions) has a considerable contribution to the financial performance measured as return on sales (ROS), with an $\mathrm{R}^{2}$ of $36.7 \%$, as shown in Table 4.

Table 4. Regression analysis results

\begin{tabular}{|c|c|}
\hline Variables & Dependent variable ROS \\
\hline Intercept & $-0.426^{* * *}$ \\
\hline GHG emissions & $-0.013^{* * *}$ \\
\hline SIZE & $0.028^{* * * *}$ \\
\hline GROWTH & $0.077^{*}$ \\
\hline DISSUE & $0.106^{* * * *}$ \\
\hline $\mathrm{CF}$ & $0.380^{* * * *}$ \\
\hline $\mathrm{CZ}$ & $-0.064^{* *}$ \\
\hline $\mathrm{HU}$ & -0.041 \\
\hline PL & -0.019 \\
\hline SK & -0.023 \\
\hline 2016 & -0.022 \\
\hline 2017 & 0.016 \\
\hline 2018 & -0.007 \\
\hline 2019 & $-0.051^{*}$ \\
\hline Country FE & Yes \\
\hline Year FE & Yes \\
\hline $\mathrm{R}^{2}$ & 0.367 \\
\hline Adjusted $\mathrm{R}^{2}$ & 0.299 \\
\hline F-stat, df $(13,133)$ & $5.356^{* * * *}$ \\
\hline Number of firms & 34 \\
\hline Number of observations & 134 \\
\hline
\end{tabular}

Note: Significance at the level of: *** $\mathrm{p}<0.01 ; * * \mathrm{p}<0.05 ; * \mathrm{p}<0.10$ 
GHG emissions have a negative and statistically significant impact on return on sales, contrary to Elsayed and Paton (2004), as well as Earnhart and Lizal (2007), who found no significant impact on this type of financial performance measure. However, our findings are similar to prior studies (De Burgos-Jiménez et al., 2013 and Fujii et al., 2013) on environmental performance, showing that companies' efforts on controlling GHG emissions enhance their financial performance.

In contrast to the GHG emissions impact, all control variables have a positive association with the dependent variable ROS, significant at the $1 \%$ level in the case of SIZE, DISSUE, and CF, respectively significant at the $10 \%$ level for GROWTH. This implies that the greater these control variables are, the higher is the firm's financial performance. Moreover, CF shows the highest coefficient, revealing a significant correlation between cash flows and revenue from sales.

Regarding the creation of dummy variables used in the model, RO was set as reference for the COUNTRY variable and 2015 was selected as basis for the YEAR variable, in order to facilitate the comparison with the SDGs' year of issuance. The results for COUNTRY show a negative, but significant influence on ROS only for CZ. This implies that increases in GHG emissions in Czech Republic will have a lower impact on return on sales compared to Romania. The findings for YEAR reveal a positive influence for 2017 and a negative influence for the other years, with significant statistical values at the $10 \%$ level for 2019, emphasising that an increase in GHG emissions in 2019 has a lower impact on ROS compared to 2015, in terms of the stakeholders' perception regarding the companies' disclosures of GHGs emissions in their annual or sustainability reports.

Data used in the multiple linear regression model show no multicollinearity as presented in Table 5. The tolerance and variance inflation factor for all variables included in the regression model are within the normal intervals: for tolerance, all values are greater than 0.1 and for VIF, all values are smaller than 10 . 
Table 5. Collinearity Statistics

\begin{tabular}{ccc}
\hline \multirow{2}{*}{ Variables } & \multicolumn{2}{c}{ Collinearity Statistics } \\
\cline { 2 - 3 } & Tolerance & VIF \\
\hline GHG emissions & 0.509 & 1.963 \\
SIZE & 0.470 & 2.127 \\
GROWTH & 0.908 & 1.102 \\
DISSUE & 0.901 & 1.110 \\
CF & 0.853 & 1.173 \\
CZ & 0.486 & 2.057 \\
HU & 0.392 & 2.554 \\
PL & 0.585 & 1.711 \\
SK & 0.395 & 2.534 \\
2016 & 0.557 & 1.794 \\
2017 & 0.511 & 1.955 \\
2018 & 0.492 & 2.032 \\
2019 & 0.510 & 1.962 \\
\hline
\end{tabular}

All above-mentioned results regarding the check of assumptions confirmed the statistical validity of the regression model used in our study.

To enrich our investigation, the cross-country analysis (González-Sánchez \& Martín-Ortega, 2020) and longitudinal analysis (Liu \& Hong Yang, 2018) were performed.

(b) Regression results - cross-country analysis

The comparative analysis between countries points out that the regression model' goodness of fit is significant at the level of 5\% for Hungary and Romania, respectively $1 \%$ for Slovakia. Reduced levels of reported GHG emissions contribute to return on sales only for companies operating in Hungary and in Slovakia, explained by the negative coefficient statistically significant at the level of $10 \%$ and at the level of 5\%, respectively.

In terms of the impact of control variables, as expected, firm size is positively influencing the financial performance (with significance at the level of $1 \%$ in Slovakia and 5\% in Hungary, respectively); this result might be justified by the fact that the major chemical companies included in our analysis are operating in Slovakia and Hungary.

For companies located in Czech Republic and Poland none of the variables are significant in explaining the performance expressed as return on sale. 
The findings of the cross-country analysis should be interpreted with caution, as there are inconsistencies generated by the disclosure policies' differences that are characterising the considered reports and that are leading to a comparison across countries to be problematic (Dingwerth \& Eichinger, 2010).

Table 6. Regression analysis results

\begin{tabular}{|c|c|c|c|c|c|c|}
\hline \multirow{2}{*}{$\begin{array}{c}\text { Dependent } \\
\text { variable ROS/ } \\
\text { Indicators } \\
\end{array}$} & \multirow{2}{*}{$\begin{array}{l}\text { Entire sample } \\
\text { (all countries) }\end{array}$} & \multicolumn{5}{|c|}{ Cross-country analysis } \\
\hline & & $\mathbf{C Z}$ & HU & PL & RO & SK \\
\hline Intercept & $-0.426^{* * *}$ & -0.327 & $-0.432^{* *}$ & -0.063 & -0.775 & $-0.692^{\text {**** }}$ \\
\hline GHG emissions & $-0.013^{* * *}$ & 0.001 & $-0.011^{*}$ & -0.024 & -0.027 & $-0.020^{* * *}$ \\
\hline SIZE & $0.028^{* * *}$ & 0.016 & $0.024^{* *}$ & 0.016 & 0.043 & $0.043^{* * * *}$ \\
\hline GROWTH & $0.077^{*}$ & 0.033 & $0.101^{* *}$ & 0.145 & -0.339 & 0.158 \\
\hline DISSUE & $0.106^{* * * *}$ & 0.030 & -0.066 & 0.182 & $0.262^{* *}$ & 0.104 \\
\hline $\mathrm{CF}$ & $0.38^{* * * *}$ & 0.889 & 0.282 & 1.270 & $0.407^{*}$ & -0.099 \\
\hline $\mathrm{CZ}$ & $-0.064^{* * *}$ & - & - & - & - & - \\
\hline $\mathrm{HU}$ & -0.041 & - & - & - & - & - \\
\hline PL & -0.019 & - & - & - & - & - \\
\hline SK & -0.023 & - & - & - & - & - \\
\hline 2016 & -0.022 & 0.032 & 0.050 & -0.044 & 0.003 & $-0.076^{*}$ \\
\hline 2017 & 0.016 & 0.024 & 0.054 & -0.021 & 0.155 & $-0.076^{*}$ \\
\hline 2018 & -0.007 & 0.019 & 0.031 & -0.069 & 0.127 & -0.042 \\
\hline 2019 & $-0.051^{*}$ & 0.004 & -0.035 & -0.189 & 0.118 & -0.048 \\
\hline Country FE & Yes & - & - & - & - & - \\
\hline Year FE & Yes & Yes & Yes & Yes & Yes & Yes \\
\hline $\mathrm{R}^{2}$ & 0.367 & 0.240 & 0.454 & 0.736 & 0.746 & 0.736 \\
\hline $\begin{array}{c}\text { F-stat } \\
\text { df }\end{array}$ & $\begin{array}{l}5.356^{* * * *} \\
(13,133)\end{array}$ & $\begin{array}{c}0.560 \\
(9,25)\end{array}$ & $\begin{array}{l}2.582^{* *} \\
(9,37)\end{array}$ & $\begin{array}{l}2.480 \\
(9,17)\end{array}$ & $\begin{array}{l}3.265^{* *} \\
(9,19)\end{array}$ & $\begin{array}{c}6.830^{* * * *} \\
(9,31)\end{array}$ \\
\hline $\begin{array}{l}\text { Number of firm- } \\
\text { year observations }\end{array}$ & 134 & 26 & 38 & 18 & 20 & 32 \\
\hline
\end{tabular}

Note: Significance at the level of: $* * * \mathrm{p}<0.01 ; * * \mathrm{p}<0.05 ; * \mathrm{p}<0.10$

(c) Regression results - longitudinal analysis

The longitudinal analysis for the time frame 2015 - 2019 reveals that, although the reliability of the model is satisfactory for the years 2015 (at level of 10\%) and 2017 (at the level of 5\%), the GHG emissions become statistically significant only starting with 2019 , as shown by the negative coefficient of this variable (-0.018 at the $10 \%)$.

The leverage ratio variable (DISSUE) is significant in 2017 and 2018 (at the 5\% level) similar to the findings of Chithambo et al. (2019). The size of the company is 
an important driver for the firms' performance expressed as return on sales (ROS) in 2017, 2018 and 2019.

The longitudinal analysis for the selected countries and companies is based on a limited number of firm-year observations and does not reflect an increase of the influence of GHG emissions reported over the period 2015-2019. This result could be the outcome of companies' inability to identify any advantages from GHG reporting or of their reports being scarce or incomplete.

Table 7. Regression analysis results

\begin{tabular}{|c|c|c|c|c|c|c|}
\hline \multirow{2}{*}{$\begin{array}{c}\text { Dependent } \\
\text { variable ROS/ } \\
\text { Indicators } \\
\end{array}$} & \multirow{2}{*}{$\begin{array}{c}\text { Entire sample } \\
\text { (all years) }\end{array}$} & \multicolumn{5}{|c|}{ Longitudinal analysis } \\
\hline & & 2015 & 2016 & 2017 & 2018 & 2019 \\
\hline Intercept & $-0.426^{* * *}$ & -0.597 & -0.308 & $-0.546^{*}$ & -0.399 & -0.338 \\
\hline GHG emissions & $-0.013^{* * *}$ & -0.014 & -0.006 & -0.014 & -0.008 & $-0.018^{*}$ \\
\hline SIZE & $0.028^{* * * *}$ & 0.033 & 0.018 & $0.034^{* *}$ & $0.026^{*}$ & $0.025^{*}$ \\
\hline GROWTH & $0.077^{*}$ & 0.085 & 0.098 & 0.067 & 0.052 & 0.125 \\
\hline DISSUE & $0.106^{* * *}$ & 0.087 & -0.071 & $0.160^{* *}$ & $0.164^{* *}$ & -0.042 \\
\hline $\mathrm{CF}$ & $0.38^{* * *}$ & 0.672 & 0.172 & 0.310 & 0.377 & 0.272 \\
\hline $\mathrm{CZ}$ & $-0.064^{* *}$ & -0.015 & 0.036 & -0.058 & -0.101 & -0.103 \\
\hline $\mathrm{HU}$ & -0.041 & -0.001 & 0.044 & 0.009 & -0.101 & -0.102 \\
\hline PL & -0.019 & 0.104 & 0.087 & 0.045 & -0.069 & $-0.113^{*}$ \\
\hline SK & -0.023 & 0.063 & 0.031 & -0.080 & -0.065 & -0.005 \\
\hline 2016 & -0.022 & - & - & - & - & - \\
\hline 2017 & 0.016 & - & - & - & - & - \\
\hline 2018 & -0.007 & - & - & - & - & - \\
\hline 2019 & $-0.051^{*}$ & - & - & - & - & - \\
\hline Country FE & Yes & Yes & Yes & Yes & Yes & Yes \\
\hline Year FE & Yes & - & - & - & - & - \\
\hline $\mathrm{R}^{2}$ & 0.367 & 0.668 & 0.536 & 0.648 & 0.437 & 0.398 \\
\hline $\begin{array}{c}\text { F-stat } \\
\text { df }\end{array}$ & $\begin{array}{c}5.356^{* * * *} \\
(13,133)\end{array}$ & $\begin{array}{l}2.461^{*} \\
(9,20)\end{array}$ & $\begin{array}{l}1.666 \\
(9,22)\end{array}$ & $\begin{array}{c}3.677^{* * * *} \\
(9,27)\end{array}$ & $\begin{array}{l}1.894 \\
(9,31)\end{array}$ & $\begin{array}{l}1.467 \\
(9,29)\end{array}$ \\
\hline $\begin{array}{c}\text { Number of firm- } \\
\text { year } \\
\text { observations }\end{array}$ & 134 & 21 & 23 & 28 & 32 & 30 \\
\hline
\end{tabular}

Note: Significance at the level of: $* * * \mathrm{p}<0.01 ; * * \mathrm{p}<0.05 ; * \mathrm{p}<0.10$ 


\section{Conclusion and further research}

This study aimed to explore the extent to which the GHG emissions influence companies' financial performance measured as return on sales. Thus, a multiple linear regression model was designed with ROS as the dependent variable, GHG emissions as the independent variable, along with four control variables for firm size (SIZE), change in sales (GROWTH), change in liabilities (DISSUE), and cash flows (CF), as well as two dummy variables for country (COUNTRY) and year (YEAR). The model is statistically significant at the $1 \%$ level and validates our hypothesis. Our findings reveal that reported GHG emissions have a negative influence on financial performance, based on the negative coefficient obtained for the independent variable with statistical significance at the $1 \%$ level. Hence, from the perspective of environmental performance, measured in terms of controlling the GHG emissions, our results emphasise that it positively influences the corporates' financial performance, similar to prior studies conducted by De Burgos-Jiménez et al. (2013) and Fujii et al. (2013).

To extend the analysis, we performed both a cross-country and longitudinal analysis. In respect of the cross-country analysis, our results underline the lack of consistency and unconvincing outcomes that can be explained by the development status of countries or the absence of mature stakeholders requesting for more and pertinent information.

Complementary to the cross-country analysis, the longitudinal analysis was conducted to ascertain the evolution of GHG reporting and its impact on return on sales (ROS), but considering the limited dataset for each year, applying prudence is recommended in interpreting the results.

This study is subject to several limitations that could be inspiring future research directions. The limits concern the reduced sample size and data collection. On the one hand, the sample was significantly reduced due to the lack of environmental and/or financial information disclosed in the sustainability or annual reports of companies and on the other hand, the process of gathering data from reports might by prone to subjectivity. Furthermore, such studies are confronted with limited available data related to quantifying the benefits of GHG reporting in monetary terms, especially when CEE countries are investigated. Most of the companies included in our study are not listed, hence the market-based variables could not be included in the regression model. As a consequence of their historical background, the selected countries (CZ, HU, PL, RO, SK) are still reluctant in disclosing information to external stakeholders or they did not find the suitable instruments for measuring and reporting their non-financial data. 
Future research might consider applying the present analysis from the perspective of long-term performance influence, such as Tobin's q, in order to observe the extent to which the market perceives long-term value in the reduction of GHG emissions. It would also be of interest to expand the sample and investigate the research question in comparison with developed economies as well.

This study makes several contributions to the literature on climate change. Firstly, the results reveal a negative but significant effect of GHG emissions on financial performance, compared to previous studies conducted by Earnhart and Lizal (2007), as well as Elsayed and Paton (2004), who obtained a highly insignificant or even no significant impact, respectively. Secondly, our evidence is in line with the majority of the results from prior empirical studies and meta-analyses that have pointed to a positive relationship between CSR and CFP (Wang et al., 2015). Thirdly, our findings confirm the specific connection between pollution emissions and customers' behaviour. Customers may respond to positive social performance by increasing their demand for the firm's products or services (Bhattacharya and Sen, 2003). Over time, the higher level of GHG emissions will lead to the decrease of the customer's confidence in the company. With the growing awareness of people about the negative effect on the climate of these gas emissions, the companies that today pay less attention to this global concern, tomorrow will face difficulties in terms of sales.

Similar to the findings of Liesen et al. (2015), companies included in our investigation might be showing an incomplete disclosure of non-financial information either as a symbolic gesture to reduce their risks exposure or because this type of reporting is unstructured and providing more detailed information is only voluntary. Additionally, there is a limited consensus in setting minimum requirements in terms of non-financial reporting, leading to a deficiency in ensuring the comparability between companies reports.

This study points out that companies, investors, consumers, as well other stakeholders may face several difficulties when analysing or comparing the various of GHG reporting methods and initiatives which are currently in use. Companies show that they are ready to set noteworthy internal targets (Milu \& Hategan, 2019; Nechita et al., 2020b) to mitigate the GHG emissions and demonstrate progress to their stakeholders. It is well-known that large-scale reduction in GHG emissions is often driven by mandatory regulations, but leading voluntary strategies has also proved to be contributing to a considerable progress on the GHG reduction (EC, 2010; González-Sánchez \& Martín-Ortega, 2020; Iordache et al., 2021).

In the chemical sector, the benefits of GHG reporting appear to vary according to the companies' size, leverage ratio, cash flow, as well as growth and are linked to the firms' overall perspective on the importance of tackling climate change issues. Considering the current still relatively undeveloped stage of GHG emissions 
reporting of the analysed Central Eastern European countries (CZ, HU, PL, RO, SK), it was expected for stakeholders' needs to be satisfied only by companies' engagement in the process of sustainability awareness. The alignment toward a global approach becomes necessary for the sustainability information to achieve its full potential, approach that should replace the current fragmented, jurisdiction-byjurisdiction practices.

By adopting a comprehensive approach, inviting businesses to disclose not only financial performance information, but also non-financial key indicators, the reporting system will provide an improved background for the decision-making process in the Anthropocene era.

\section{Acknowledgements}

The paper was presented in the 16th International Conference Accounting and Management Information Systems AMIS 2021, Bucharest, Romania and the authors benefited of the debates and recommendations of the participants. The current version of paper integrates the valuable recommendations of the participants to the conference.

\section{References}

Albertini, E. (2013) „Does environmental management improve financial performance? A meta-analytical review", Organization \& Environment, vol. 26, no 4: 431-457

Barth, M.E., Landsman, W. \& Lang, M. (2008) „International accounting standards and accounting quality", Journal of Accounting Research, vol. 46: 467-498

Bartlett, B.D. (2012) "The effect of corporate sustainability reporting on firm valuation. CMC Senior Theses." Paper 489, available online at http://scholarship.claremont.edu/cmc_theses/489 (accessed on 30 August 2020)

Belal, A.R. (2001) "A study of corporate social disclosures in Bangladesh", Managerial Auditing Journal, vol. 16, no. 5: 274-289

Bhattacharya, C. B., \& Sen, S. (2003) „Consumer-company identification: A framework for understanding consumers 'relationships with companies.", Journal of Marketing, vol. 67, no.2: 76-88

Budiharjo, R. (2019) „Effect of environmental performance and financial performance on firm value", International Journal of Academic Research in Accounting, Finance and Management Sciences, vol. 9, no. 2: 65-73

Carson, R. (1962) Silent Spring. Boston: Houghton Mifflin

Chithambo, L., Tingbani, I. Afrifa, G., Agyapong, G. A., Gyapong, E., Damoah, I.S. (2019) "Corporate voluntary greenhouse gas reporting: Stakeholder pressure and the mediating role of the chief executive officer", Business Strategy and The Environment, vol. 29, no. 4: 1666-1693 
CIMA, Chartered Institute of Management Accountants (2010) „Accounting for climate change", available online at https://testsecure.cimaglobal.com/ Documents/Thought_leadership_docs/cid_accounting_for_climate_change_f eb10.pdf

Clarkson, P.M., Overell, M.B.\& Chapple, L. (2011) „Environmental reporting and its relation to corporate environmental performance", Abacus, vol. 47: 27-60

Cook, R.D.\& Weisberg, S. (1982) Residuals and Influence in Regression, Chapman \& Hall: New York, NY, USA

Cormier, D., Magnan, M. \& Van Velthoven, B. (2005) "Environmental disclosure quality in large German companies: Economic incentives, public pressures or institutional conditions?", European Accounting Review, vol. 14, no. 1: 3-39

Cotter, J. \& Najah, M.M (2011) „Institutional investor influence on global climate change disclosure practices" Australian Journal of Management, vol. 37, no. 2: $169-187$

De Burgos-Jimenez, J., Vázquez-Brust, D., Plaza-Úbeda, J.A. \& Dijkshoorn, J. (2013) „Environmental protection and financial performance: an empirical analysis in Wales", International Journal of Operational and Production Management. vol. 33, no. 8: 981-1018

Delmas, M.A., Nairn-Birch, N.\& Lim, J. (2015) „Dynamics of environmental and financial performance: the case of Greenhouse Gas Emissions", Organization \& Environment, vol. 28, no. 4: 374-393

Dingwerth, K. \& Eichinger, M. (2010) "Tamed transparency: how information disclosure under the global reporting initiative fails to empower", Global Environmental Politics, vol. 10, no. 3: 74-96

Doran, K. L. \& Quinn, E. L. (2009) „Climate change risk disclosure: a sector by sector analysis of SEC 10-K Filings from 1995-2008”, North Carolina Journal of International Law and Commercial Regulation, vol. 34, no. 3: $725-26$

Dowell, G., Hart, S. \& Yeung, B. (2000) „Do corporate global environmental standards create or destroy market value?", Management Science, vol. 46, no. 8: 1059-1074

Earnhart, D. \& Lizal, L. (2007) „Effect of pollution control on corporate financial performance in a transition economy", European Environment, vol. 17, no. 4: 247-266, Published online in Wiley InterScience (www.interscience. wiley.com) DOI: 10.1002/eet.447

EC. Company GHG Emissions Reporting - a Study on Methods and Initiatives (ENV.G.2/ETU/2009/0073) https://ec.europa.eu/environment/pubs/pdf/ERM _GHG_Reporting_final.pdf

Elsayed, K., \& Paton, D. (2004) „The impact of environmental performance on firm performance: static and dynamic panel data evidence", Structural Change and Economic Dynamics, vol. 16, no. 3: 395-412

European Environment Agency (2019). Annual European Union Greenhouse Gas Inventory 1990-2017 and Inventory Report 2019. Submission to the UNFCCC Secretariat. 2019. Available online: https://unfccc.int/documents/194921 
European Environment Agency, (2021) „Industrial pollution country profiles”, available online: https://www.eea.europa.eu/themes/industry (accessed on 30 March 2021).

EY (2019) „How climate change disclosures reveal business risks and opportunities", available online at https://www.ey.com/en_gl/assurance/ climate-change-disclosures-revealing-risks-opportunities

Freeman, R.E. (1984) Strategic Management: A Stakeholder Approach, Pitman, Boston, MA

Fujii, H., Iwata, K., Kaneko, S. \& Managi, S. (2013) „Corporate environmental and economic performances of Japanese manufacturing firms: Empirical study for sustainable development", Business Strategy and the Environment, vol. 22, no. $3: 187-201$

García-Sánchez, I.M. \& Prado-Lorenzo, J.M. (2012) "Greenhouse gas emission practices and financial performance" International Journal of Climate Change Strategy Management, vol 4: 260-276, http://dx.doi.org/10.1108/ 17568691211248720

Ghomi, Z.B. \& Leung, P. (2013) "An empirical analysis of the determinants of greenhouse gas voluntary disclosure in Australia", Accounting and Finance Research, vol. 2, no. 1

Gnanaweera, K. \& Kunori, N., (2016) „The empirical study of corporate environmental performance and financial performance: Assessing corporate social responsibility in Japan", The $13^{\text {th }}$ International Conference on Business Management (ICBM), University of Sri Jayewardenepura, Sri Lanka, available online at SSRN: https://ssrn.com/abstract=2910299

Goll, I. \& Rasheed, A.A. (2004) „The moderating effect of environmental munificence and dynamism on the relationship between discretionary social responsibility and firm performance" Journal of Business Ethics, vol. 49, no.1: 41-54, doi:10.1023/B: BUSI.0000013862.14941.4e.

González-Sánchez, M. \& Martín-Ortega, J.L. (2020) "Greenhouse gas emissions growth in Europe: A comparative analysis of determinants", Sustainability vol. 12, doi:10.3390/su12031012

Grimaldi, F., Caragnano, A., Zito, M. \& Mariani, M. (2020) „Sustainability engagement and earnings management: The Italian context", Sustainability, vol. 12 , no. 12 : 48-81

Hair, J.F., Black, W. C., Babin, B.J. \& Anderson, R.E. (2014) Multivariate data analysis $\left(7^{\text {th }}\right.$ ed.). Harlow, England: Pearson

Heijden, J. (2019) „Studying urban climate governance: Where to begin, what to look for, and how to make a meaningful contribution to scholarship and practice", Earth System Governance, vol. 1, 100005, https://doi.org/10.1016/ j.esg.2019.100005

Hoffman, A. J. \& Bansal, P. (2011) Retrospective, Perspective, and Prospective: Introduction to the Oxford Handbook on Business and the Natural Environment. The Oxford Handbook of Business and the Natural Environment Edited by Pratima Bansal and Andrew J. Hoffman. Print 
Publication Date: Nov 2011. Subject: Business and Management, Business Policy and Strategy, Social Issues, https://doi.org/10.1016/j.oneear. 2019.12.002

Huber, P.J. (1981) Robust Statistics, John Wiley \& Sons: New York, NY, USA

Hussain, N., Rigoni, U. \& Cavezzali, E. (2018) „Does it pay to be sustainable? Looking inside the black box of the relationship between sustainability performance and financial performance", Corporate Social Responsibility Environmental Management, vol. 25:1198-1211, doi:10.1002/csr.1631

Iordache, M., Zgavarogea, R., Iordache, A. M., Constantinescu, M., Bucura, F., Ionete, R. E., Grigorescu, R. \& Nechita, C., (2021) "Temporal evolution of greenhouse gas emissions in European Union (EU28): A perspective on Romania", Smart Energy and Sustainable Environment, vol. 24, no. 2: 43-58, https://doi.org/10.46390/j.smensuen.24221.438

IPCC (Intergovernmental Panel on Climate Change) (2013) Climate change 2013: The physical science basis. Working Group, I contribution to the IPCC Fifth Assessment Report. Cambridge, United Kingdom: Cambridge University Press. www.ipcc.ch/report/ar5/wg1

ISI Emerging Markets Group's EMIS platform database, 2020, available online: https://www.emis.com/industries/Chemicals (accessed on 4 August 2020).

Iwata H., \& Okada, K., (2011) „How does environmental performance affect financial performance? Evidence from Japanese manufacturing firms", Ecological Economics, vol. 70, no. 9:1691-1700, https://doi.org/10.1016/ j.ecolecon.2011.05.010.

Jaggi, B. \& Freedman, M. (1992a) „An examination of the impact of pollution performance on economic and market performance: pulp and paper firms", Journal of Business Finance and Accounting, vol. 19, no. 5: 697-713

Jaggi, B., Allini, A., Macchioni, R. \& Zagaria, C. (2018b) "The Factors motivating voluntary disclosure of carbon information: evidence based on Italian listed companies", Organization \& Environment, vol. 31, no. 2: 178-202

King, A., \& Lenox, M. (2002) „Exploring the locus of profitable pollution reduction", Management Science, vol. 48, no.2: 289-299

Konar, S. \& Cohen, M.A. (2000) Does the market value environmental performance, Working paper, Vanderbilt University

KPMG (2015) Climate change and corporate value, available online at: https://home.kpmg/xx/en/home/insights/2020/11/climate-change-andcorporate-value-what-companies-really-think.html, accessed March, 2021

Kuzey, C.\& Uyar, A. (2017) "Determinants of sustainability reporting and its impact on firm value: Evidence from the emerging market of Turkey", Journal of cleaner production, vol. 143: 27-39

Liesen, A., Hoepner, A.G., Patten, D.M. \& Figge, F. (2015) "Does stakeholder pressure influence corporate GHG emissions reporting? Empirical evidence from Europe", Accounting, Auditing \& Accountability Journal, vol. 28, no: $1047-1074$ 
Line, M., Hawley, H. \& Krut, R. (2002) "The development of global environmental and social reporting", Corporate environmental strategy, vol. 9: 69-78

Liu, Y.S. \& Hong Yang J. (2018) "A longitudinal analysis of corporate greenhouse gas disclosure strategy", Corporate Governance, vol. 18, no. 2: 317-330

Lopez-Gamero, M.D., Molina-Azorın, J.F. \& Claver-Cortes, E. (2009) „The whole relationship between environmental variables and firm performance: Competitive advantage and firm resources as mediator variables", Journal of Environmental Management, vol. 90, no. 10: 3110-3121; DOI: 10.1016/j.jenvman.2009.05.007

Manrique, S. \& Martí-Ballester, C.P (2017) „Analyzing the effect of corporate environmental performance on corporate financial performance in developed and developing countries", Sustainability, vol. 9, no. 11: 19-57; doi:10.3390/su9111957

McWilliams, A. \& Siegel, D. (2000) „Corporate Social Responsibility and financial performance: correlation or misspecification? “, Strategic Management Journal, vol. 21, no. 5: 603-609

Milu, N.D. \& Hategan, C.D. (2019) "Transparency degree of non-financial information disclosure" Analele Universitatii Ovidius Constanta, vol. XIX, no. 2: 806-811

Mion, G., Adaui, L. \& Mandatory, C.R. (2019) „Nonfinancial disclosure and its consequences on the sustainability reporting quality of Italian and German companies", Sustainability, vol. 11, 4612

Mishra, S.\& Suar, D. (2010) „Does corporate social responsibility influence firm performance of Indian companies? “, Journal of Business Ethics, vol. 95, no. 4: 571-601, doi:10.1007/s10551-010-0441-1

Moore, G. M. (2001) „Corporate Social Performance: an investigation in the U.K. Supermarket Industry “, Journal of Business Ethics, vol. 34, no. 3-4: 299-315

Mummolo, J. \& Peterson, E. (2018) "Improving the interpretation of fixed effects regression results", Political Science Research and Methods, vol. 6, no. 4: 829-835, doi:10.1017/psrm.2017.44.

Nechita, E., Manea, C. L., Nichita, E-M, Irimescu. A. M \& Manea, D. (2020b) „Is financial information influencing the reporting on SDGs? Empirical evidence from Central and Eastern European chemical companies", Sustainability vol. 12, doi:10.3390/su12219251

Nechita, E., Manea, C.L., Irimescu. A.M. \& Nichita, E-M. (2020a) „The content analysis of reporting on Sustainable Development Goals", Audit Financiar, vol. XVIII, no. 4(160): 831-854, DOI: 10.20869/AUDITF/2020/160/030

OECD (2015) Climate change disclosure in G20 countries. Stocktaking of corporate reporting schemes, https://www.oecd.org/daf/inv/mne/Report-on-Climatechange-disclosure-in-G20-countries.pdf

Pinkse, J. \& Kolk, A. (2009) International business and global climate change. New York, NY: Routledge

Porter, M., \& Reinhardt, F. (2007) „Grist: A strategic approach to climate. Forethought”, Harvard Business Review, vol. 85, no. 10: 22-26 
Rassier, D. (2005) Does Environmental Regulation Affect Financial Performance? Evidence from Permitted Limits and Intervention Data, University of Kansas - Department of Economics, mimeograph.

Rassier, D. G. \& Earnhart, D. (2010) "Does the Porter hypothesis explain expected future financial performance? The effect of clean water regulation on chemical manufacturing firms", Environmental and Resource Economics, vol. 45, no. 3: $353-377$

Retolaza, J.L., San-Jose, L. \& Ruíz-Roqueñi, M. (2016) Social accounting for sustainability monetizing the social value, Springer International Publishing: 2016

Roberts, R.W. (1992) "Determinants of corporate social responsibility disclosure: an application of stakeholder theory", Accounting, Organizations and Society, vol. 17 , no. 6: 595-612

Sarkis, J. \& Cordeiro, J. J. (2001) „An empirical evaluation of environmental efficiencies and firm performance: pollution prevention versus end-of-pipe practice", European Journal of Operational Research, vol.135, no. 1: $102-113$

Sprengel, D.C., \& Busch, T. (2010) "Stakeholder engagement and environmental etrategy - the case of climate change", Business Strategy and the Environment, vol. 20, no. 6:351-364

Stanwick, P.\& Stanwick, S. (1998) „The relationship between corporate social performance and organizational size, financial performance, and environmental performance: an empirical examination", Journal of Business Ethics, vol. 17, no. 2: 195-204

Trumpp, C. \& Guenther, T. (2017) „Too little or too much? Exploring U-shaped relationships between corporate environmental performance and corporate financial performance", Business Strategy Environment, vol. 26, no. 1:49-68

Trutnevyte, E., Hirt, L., Bauer, N., Cherp, A., Hawkes, A., Edelenbosch, O.Y., Pedde, S. \& Vuuren, D.P. (2019) „Societal transformations in models for energy and climate policy: The Ambitious Next Step", One Earth, vol.1, no. 4: 423-433

United Nations (1992) „United Nations Framework Convention on Climate Change", available on-line at https://unfccc.int/files/essential_background/ background_publications_htmlpdf/application/pdf/conveng.pdf

Walley, N. \& Whitehead, B. (1994) "It's not easy being green", Harvard Business Review, vol. 72, no. 3: 46-52

Wang, L., Li, S.\& Gao, S., (2014) „Do Greenhouse Gas Emissions affect financial performance? - an empirical examination of Australian public firms", Business Strategy and the Environment, vol. 23, no. 8: 505-519

Wang, Q., Dou, J. \& Jia, S., (2015) „A meta-analytic review of Corporate Social Responsibility and corporate financial performance: the moderating effect of contextual factors", Business \& Society, 1-39, DOI: 10.1177/0007650315584317bas.sagepub.com 